\title{
Whey, Waste or Value?
}

\author{
Nayil Dinkci* \\ Ege University, Faculty of Agriculture, Department of Dairy Technology, Izmir, TURKEY
}

*Corresponding author: Nayil Dinkci, Ege University, Faculty of Agriculture, Department of Dairy Technology, Izmir, TURKEY.

\section{Received Date: April 09, 2021}

Published Date: April 20, 2021

\section{Introduction}

The dairy industry has effluents of different characteristics, according to the product obtained (yogurt, cheese, butter, milk, ice cream, etc.). By-products contain various valuable nutrients; thus, their reuse in the production process allows efficient exploitation of all nutrients available in raw milk. The processing of dairy products becomes a complex network of interrelated production processes. Often, production of a certain dairy product results in an additional residual dairy flow by-product. For instance, production of cheese results in additional production of whey and cream; production of butter results in additional buttermilk [1]. The cheese manufacturing industry produces vast volumes of aqueous wastes. It can be referred that for the production of 1 $\mathrm{kg}$ of cheese, $10 \mathrm{~kg}$ of milk are needed, originating $9 \mathrm{~kg}$ of cheese whey [2]. Whey is the major by-product of the dairy industry and its disposal without expensive sewage treatments represents a major source of environmental pollution due to the bulk quantities and its high organic load. Lactose, the major component of whey solids, contributes to its high biochemical and chemical oxygen demand (BOD, COD). It is 175-fold higher than the typical sewage effluent [3]. With increasingly strict environmental regulation of disposing of whey as waste has become difficult and costly. The growing societal focus on circular economy and the environmental pressure has forced the dairy industry to manage its whey side stream. Cheese whey is simultaneously an effluent with strong organic and saline content and nutritional value. Whey contains valuable substances that are possible to valorise, including functional proteins and peptides, lipids, vitamins, minerals and lactose [4]. In recent decades Dairies around the world have developed technologies, processing capacities, products and new business models for utilising these substances. The rapid growth in global markets for food ingredients, including whey-based protein powders, which are 'among the winners of several new nutrition trends and food developments' [5]. Thus, whey has become an important nutritional and functional ingredient for high-quality foods [6] and the global whey protein industry has been estimated to grow by $12-14 \%$ per year [7]. This strong market trend is strongly driven by the rise of 'functional nutritionism', which refers to the increased engineering and reengineering of food in coevolution with changing corporate strategies, trends in food, diets and health, and new food and nutrition policies $[5,8,9]$. An indication of this trend is the large and growing market for functional food ingredients, i.e. probiotics, proteins and amino acids, phytochemical and plant extracts, prebiotics, fibres and specialty carbohydrates, omega-3 fatty acids, carotenoids, vitamins, and minerals. In 2018 these were estimated at US\$ 68.6 billion worldwide, rising to US\$ 94.2 billion by 2023 [10].

\section{Properties of Sweet Whey}

Whey, the liquid residue of cheese, casein and yoghurt production, is one of the biggest reservoirs of food protein available today. World whey output at approximately 180 million tonnes in 2013 contains some 1.5 million tonnes of increasingly high-value protein and 8.6 million tonnes of lactose, a very important source of carbohydrate for the world [11]. Whey protein is arguably the most nutritionallyvaluable protein available; little wonder that nutritional markets such as sports, clinical and infant nutrition are driving an unprecedented investment level in dairy production. Packed full of 'natural goodies' such as high-gelling b-lactoglobulin, mother's milk equivalent protein a-lactalbumin, lactoferrin, and immunoglobulin 
and as a pre-cursor to the probiotic galactooligosaccharides (GOS), whey is proving to be one of the most exciting nutrient sources available today. Whey as a by-product from the manufacture of hard, semi-hard or soft cheese and rennet casein is known as

Table 1: Approximate composition of separated whey, \% [11]. sweet whey and has a pH of 5.9 - 6.6. Manufacture of mineral-acid precipitated casein yields acid whey with a $\mathrm{pH}$ of $4.3-4.6$. Table 1 shows approximate composition figures for whey from cheese and casein manufacture.

\begin{tabular}{|c|c|c|}
\hline & Cheese Whey & HCl Acid Casein Whey \\
\hline Constituent & $\%$ & 6.4 \\
\hline Total Solids & 6 & 93.6 \\
\hline Water & 94 & 0.05 \\
\hline Fat & 0.05 & 0.6 \\
\hline True Protein & 0.6 & 0.2 \\
\hline NPN (Non-Protein Nitrogen) & 0.2 & 4.6 \\
\hline Lactose & 4.5 & 0.8 \\
\hline Ash (Minerals) & 0.5 & 0.12 \\
\hline Calcium & 0.035 & 0.065 \\
\hline Phosphorus & 0.04 & 0.05 \\
\hline Sodium & 0.045 & 0.16 \\
\hline Potassium & 0.14 & 0.11 \\
\hline Chloride & 0.09 & 0.05 \\
\hline Lactic Acid & 0.05 & \\
\hline
\end{tabular}

Advances in membrane filtration and chromatography have underpinned economically viable commercial processes for the fractionation of whey into highly purified protein and lactose products that allow end users to take advantage of the various functional properties of individual whey components. Table 2 lists some fields of application for whey and whey products. The block diagram in Figure 1 summarizes various processes used in the treatment of whey and its end products. The first stage is filtering the curd particles left in the whey, followed by separation of casein fines and fat. Production of whey powder, Delactosed whey and lactose has traditionally dominated processing of whey solids. However, the increased demand for whey proteins results in approximately $40 \%$ of processed whey solids being directed to associated products WPC 35-80, whey protein isolate (WPI), lactose and permeate. The shift in the image of whey from an unwanted byproduct to a highly valuable nutritional source is complete.

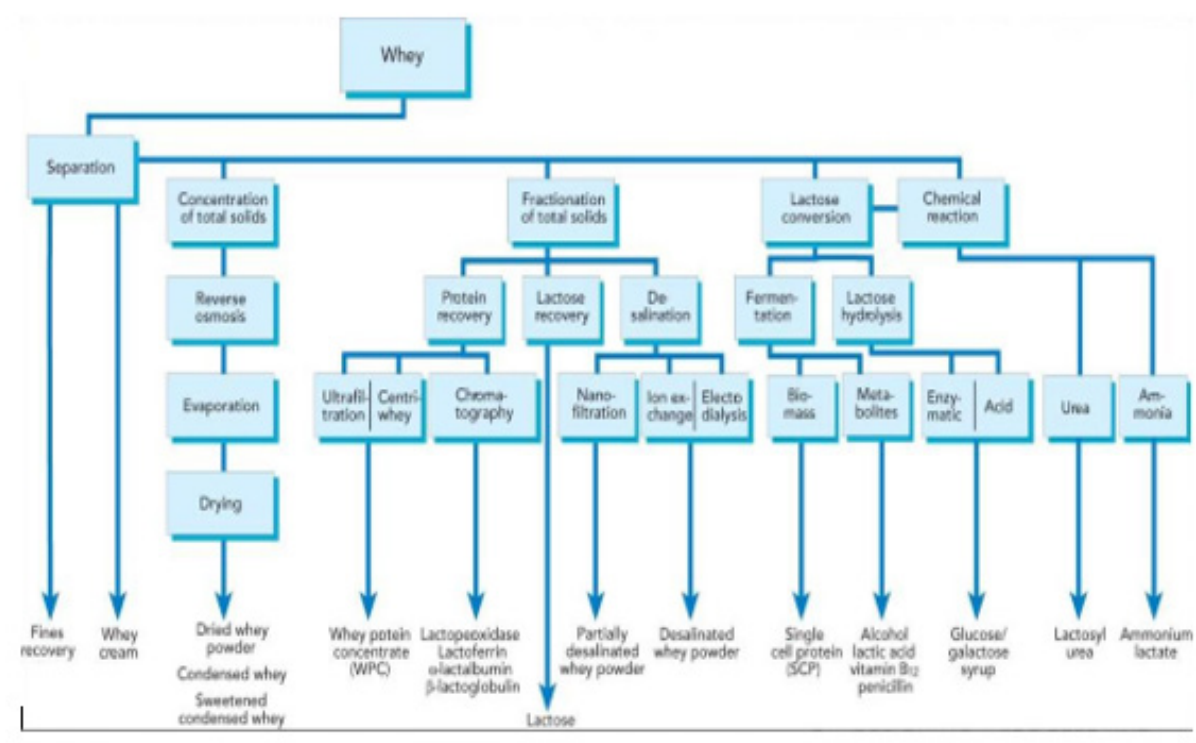

Figure 1: Utilization of whey and whey products [11]. 


\begin{tabular}{|c|c|c|c|c|c|c|c|c|c|c|c|c|c|c|c|c|c|c|}
\hline \multirow{3}{*}{ 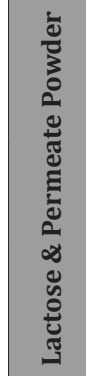 } & 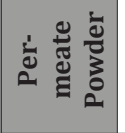 & $\rtimes$ & & & & & & & 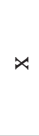 & $\star$ & & & & & & $\star$ & & \\
\hline & 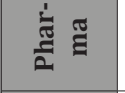 & . & & & & & & & & & & & & & & & $\star$ & \\
\hline & 㟒 & & & $\rtimes$ & & & & & & & & & & & $x$ & $x$ & & \\
\hline \multirow{6}{*}{ 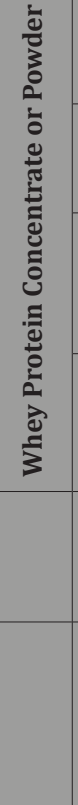 } & 苛 & & & $\rtimes$ & $x$ & & & & & & & & & & & $\rtimes$ & & \\
\hline & Еँ & & & & & & & & & & & & & & & & & $x$ \\
\hline & 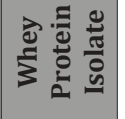 & & & & & $x$ & 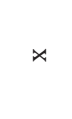 & $\rtimes$ & & & & & & & $x$ & & & \\
\hline & 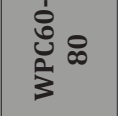 & & & $\rtimes$ & $\star$ & $\star$ & $\star$ & & & & & & & $x$ & $x$ & & & \\
\hline & $\begin{array}{l}\text { ம் } \\
\text { ஸु } \\
\sum^{2} \text { in }\end{array}$ & $\rtimes$ & & $\rtimes$ & $\rtimes$ & & & & $x$ & $\star$ & & $x$ & & & & $\rtimes$ & & \\
\hline & 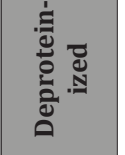 & & & & & & & & & & & & & & & & & \\
\hline \multirow{3}{*}{ 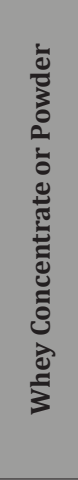 } & 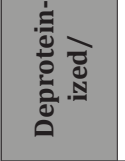 & & & & & & & & & & & & & & & & & \\
\hline & 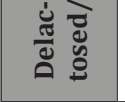 & $\rtimes$ & & & & & & & & & & & & & & & & \\
\hline & 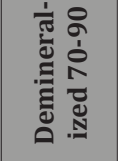 & & & $x$ & & & & & & & & & & & & & & \\
\hline \multirow{4}{*}{$\sum_{3}^{2}$} & 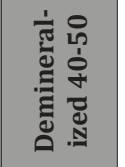 & $x$ & & & & & & & $x$ & & & & & & & $\star$ & & \\
\hline & 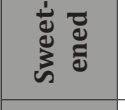 & & & & & & & & $x$ & & & & & & & $x$ & & \\
\hline & 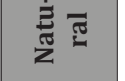 & 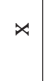 & & & & & & & $\rtimes$ & $\rtimes$ & & & $\rtimes$ & $x$ & & $\rtimes$ & & \\
\hline & 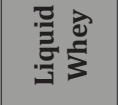 & $\star$ & & & & & & & & $\star$ & & & & & $x$ & & & $x$ \\
\hline 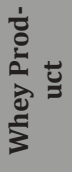 & & 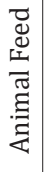 & 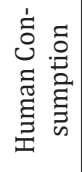 & 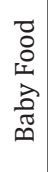 & 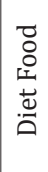 & 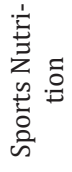 & 莺苞泀 & 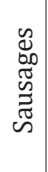 & 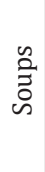 & 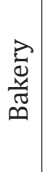 & 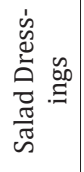 & 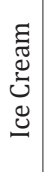 & 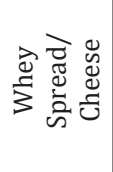 & 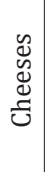 & 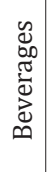 & 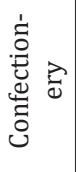 & 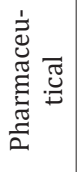 & 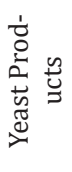 \\
\hline
\end{tabular}




\section{Properties and Uses of Acid Whey}

Acid whey is a potential hazard to the aquatic environment due to its high organic matter content in the shape of lactose, resulting in a high Biological Oxygen Demand (BOD > 35,000 ppm) and Chemical Oxygen Demand (COD > 60,000 ppm) [12,13]. The high BOD level means that the presence of acid whey in waters would cause a drop in biological oxygen levels, leading to the elimination of aquatic life. But acid whey contains many valuable compounds, providing opportunities for companies to gain competitive advantage through value-added utilisation of acid whey [14]. There are several types of whey depending on the processing technology used for the casein removal of liquid milk.

\section{Sweet whey and acid whey}

Sweet whey is a by-product from white hard cheese production and can be used to produce a range of functional and nutritional foods. Different qualities of acid whey are derived from the production of Quark, Icelandic skyr, cream cheese and cottage cheese. A variant of acid whey is casein whey, which is derived from the production of calcium caseinate. Calcium caseinate is a protein produced from casein (milk protein) in skim milk and is used in coffee creamers and instant soups and as a dietary supplement by athletes. Both sweet whey and acid whey are composed mainly of water $(93 \%)$ while the solid components consist of minerals (12-15\%), lactose (70-72\%) and whey proteins (8-10\%) [15]. The largest difference between acid whey and sweet whey is the $\mathrm{pH}$, which lies within 6.0-6.5 for sweet whey [15] and 3.6-4.5 for acid whey [16], while acid casein whey has a pH of 4.5-5.1 [15]. Overall, compared to sweet whey, acid whey has less protein, is more acidic and has a more distinct (sour) taste. The most common way to process whey into a product suitable for industrial use is to dry it through evaporation in multistage vacuum evaporators followed by spray-drying. A low pH makes the proteins less stable and it is more difficult, for instance, to remove water from acid whey than from sweet whey. Proteins are thus more readily available and easily isolated from sweet whey than from acid whey. Moreover, sweet whey can easily be heat-treated and used in new products (e.g. creamy cheese). If acid whey is heated, it will not become an acidic gel, but unites and acquires a slightly granular consistency. Research and technological innovation have transformed the utilization of sweet whey from waste (or feed) to a resource for value-added products [13]. Can such a transformation also occur for acid whey?

\section{Valorisation pathways for acid whey}

Animal feed: The use as animal feed is one of the most common uses of acid whey and sweet whey due to their nutritional properties. Acid whey is mainly a source of energy (milk sugar) rather than a protein source. Although acid whey is a suitable feed, the transport and storage of liquid whey is costly and barely profitable. Some yoghurt makers such as Chobani in the US sell it to local farmers for animal feed supplement [17].

Biogas: Another common application of acid whey is as a substrate for biogas production, where the biogas is used for electricity production. The first environmental gain of using acid whey for biogas production is the avoided risk of spillage into the environment. The second gain occurs when it replaces electricity made from non-renewable sources and reduces greenhouse gas emissions. In Turkey, some cheese plants have biogas digesters installed onsite. SÜTAŞ is an example of a company that transports whey to his nearby farm, where it is used in biogas production.

Bakery: Some research articles examine the use of the acid whey which stems from the production of the Indian cottage cheese known as paneer, as a bread ingredient $[18,19]$. Research design and results reveal the focus to be on solving the waste problem connected to acid whey.

Whey beverages: Whey beverages are drinks where whey is the main component in liquid form. There are several examples of both soft drinks and alcoholic beverages containing casein whey. The Swiss brand Rivella is the only one with a reasonable market share and lasting success. The most typical beverage combination of casein whey is with citrus fruit juices due to the high content of lactic acid. The literature also contains examples of alcoholic beverages such as beer, wine and champagne, which are produced with acid whey. Whey beverages have had very little commercial success due to processing challenges and the unusual flavour of raw whey, a more refined technology and an increasing awareness of the nutritional benefits of whey proteins may encourage the further development of whey beverages [15].

Nutritional products: Research projects have been conducted that acid whey contains several nutritional compounds, such as lactose, proteins and vitamin B12, while several articles deal with the isolation of substances such as $\beta$-lactoglobulin and $\alpha$-lactalbumin. Such single components can be used as food additives as well as for medical purposes, where earnings can be even greater. Most of these processes require complex technologies, which many dairies are reluctant to include in their production lines. This can be due to two reasons. First, this process requires new investments and a reorganization of production, second the isolation of useful components will result in even less valuable residual material, which will be less suitable for animal feed and require further processing. Casein whey is commonly used in medical nutrition. For example, MyProtein $®$ used to provide casein whey protein powder used for fitness purposes.

\section{Conclusion}

There are several potential valorization pathways for acid whey, including as a component in animal feed, nutritional products, bakery products and beverages. Yet the dominant use today is 
as animal feed or as a biogas substrate in unprocessed form. In contrast, virtually all sweet whey is upcycled to value-added products, notably a variety of whey proteins and whey permeates used in the manufacturing of nutritional and functional foods. It has become a scarce resource. Whey is the central side stream in the dairy sector and has been utilized differently. Using whey as a raw material in production processes can not only improve a company's sustainable competitive advantage; it also aids the transition towards a sustainable bio economy. Innovation in waste systems results in lower disparate rates while increasing the ability to upcycle whey, adding value to by-products in the dairy value chain. When considering alternative valorization options for byproducts such as whey, it is important to take a holistic and wholesystem perspective on sustainability. The most technologically advanced options are not necessarily the 'best' ones in terms of environmental, economic and social impacts and there will likely be trade-offs between these three dimensions of sustainability.

\section{Acknowledgement}

None.

\section{Conflict of Interest}

No conflict of interest.

\section{References}

1. Dinkçi N (2015) An Effective Way For Cheese Whey Valorisation. "Dairy Waste Valorisation Workshop" EU BIS Chemicals from Food Waste. Semmering-Wien, Austria.

2. Dinkçi N (2016) Alternative Techniques in Cheese Whey Management. 8th Central European Congress on Food "Food Science for Well-being". Kyiv, Ukraine.

3. Bolwig S, Brekke A, Strange L, Strøm-Andersen N (2019) Valorisation of whey: A tale of two Nordic dairies. In From Waste to Value: Valorisation Pathways for Organic Waste Streams in Circular Bioeconomies. Taylor \& Francis, pp. 326.

4. Smithers GW (2008) Whey and whey proteins: From 'gutter-to-gold'. International Dairy Journal 18(7): 695-704.
5. Vik J, Kvam GT (2017) Trading growth: A study of the governance of Norwegian whey protein concentrate exports. Proceedings in Food System Dynamics 8: 145-154.

6. NutritionInsight (2018) 'Big protein, small bottle': Arla Foods Ingredients to introduce whey shot concept.

7. Kjer U (2013) Valle i høj kurs.

8. Scrinis G (2013) Nutritionism: The science and politics of dietary advice. New York:Columbia University Press.

9. Scrinis G (2016) Reformulation, fortification and functionalization: Big food corporations'nutritional engineering and marketing strategies. Journal of Peasant Studies 43(1): 17-37.

10.PR Newswire (2018) Functional food ingredients: Global market outlook to 2023 - Development of different techniques to create highvaluenatural carotenoids.

11. Dairy Processing Handbook (2020) Chapter 15 Whey Processing.

12. Ramos OL, Pereira RN, Rodrigues RM, Teixeira JA, Vicente AA et al. (2015) Whey and whey powders: Production and uses. Encyclopedia of Food and Health, pp. 498-505.

13. Smithers GW (2015) Whey-ing up the options: Yesterday, today and tomorrow. International Dairy Journal 48: 2-14.

14. Guimarães PMR, Teixeira JA, Domingues L (2010) Fermentation of lactose to bio-ethanol by yeasts as part of integrated solutions for the valorisation of cheese whey. Biotechnology Advances 28: 375-384.

15. Jelen P (2011) Whey processing: Utilization and products. Encyclopedia of Dairy Sciences: Second Edition, pp. 731-737.

16. Gami SK, Godwin GS, Czymmek KJ, Ganoe KH, Ketterings QM (2016) Acid whey $\mathrm{pH}$ and nutrient content. Cornell Agronomy Factsheet \#96. Ithaca, NY: Cornell University Press.

17. Erickson BE (2017) How many chemicals are in use today? Chemical Engineering News 95(9): 23-24.

18. Divya N, Rao KJ (2010) Studies on utilization of Indian cottage cheese whey in wheat bread manufacture. Journal of Food Processing and Preservation 34: 975-992.

19. Paul S, Kulkarni S, Rao KJ (2016) Effect of Indian cottage cheese (paneer)-whey on rheological and proofing characteristics of multigrain bread dough. Journal of Texture Studies 47: 142-151 